\title{
Technoeconomic analysis of shale gas gross split contract in Naintupo Formation, Tarakan Basin
}

\author{
Wike Widyanita ${ }^{1, *}$, and Nelson Saksono ${ }^{1}$ \\ ${ }^{1}$ Department of Chemical Engineering, Faculty of Engineering Universitas Indonesia, Kampus Baru UI, Depok 16424, Indonesia
}

\begin{abstract}
The deficit of natural gas supply and demand could be minimized by discovering new reserves in conventional or unconventional reservoir. Shale gas potential in Indonesia was estimated 574 TCF and Naintupo Formation in Tarakan Basin had 5 TCF of technically recoverable reserve with 35 TCF risked gas-in-place. This study would discuss technoeconomic aspect of shale gas field development in Naintupo Formation, Tarakan Basin using gross split contract scheme. Three flow profiles would be developed by using Arps hyperbolic decline curves, consist of low flow profile with initial production $\left(\mathrm{q}_{\mathrm{i}}\right)$ of 150 $\mathrm{mmcf} / \mathrm{mo}$, medium $\left(\mathrm{q}_{\mathrm{i}}=250 \mathrm{mmcf} / \mathrm{mo}\right)$ and high flow profile $\left(\mathrm{q}_{\mathrm{i}}=350 \mathrm{mmcf} / \mathrm{mo}\right)$. Costs estimation were based on benchmarking cost of developed shale gas field in United States and nearby oil/gas field development in Tarakan Basin. Economic analysis showed that medium and high flow profile gave positive economic indicator marked by positive NPV and IRR $>10 \%$. Sensitivity analysis showed that flow profile gave more effect in NPV and IRR increased than the gas price. In order to develop positive NPV with discount rate of $10 \%$, it is required to sell shale gas at $\$ 6.52 / \mathrm{MMBTU}$ in high flow profile or $\$ 8.42 / \mathrm{MMBTU}$ in medium flow profile.
\end{abstract}

\section{Introduction}

Indonesia is facing a deficit condition in supply and demand of natural gas. In 2014, the gas supply was 6,970 MMSCFD with demand reached 9,494 MMSCFD. The Energy and Resource Ministry of Indonesia [1] projected in 2030 supply would be decreased to 3,388 MMSCFD and demand would increase to 11,144 MMSCFD. This deficit situation could be minimized by discovering new conventional gas field or by developing unconventional gas resource, such as CBM and shale gas.

Shale gas resource potential was estimated reached $574 \mathrm{TCF}$, meanwhile CBM and conventional gas potential were $453.3 \mathrm{TCF}$ and $334 \mathrm{TCF}$, respectively. Shale gas was located in main sedimentary basin in Indonesia which spread in Sumatra, Kalimantan, Java and Papua (Fig. 1).

Shale gas was natural gas trapped in shale formation which contained massive organic material to form oil and gas. Shale had very low permeability causing gas contained in this formation could not be produced by conventional drilling and completion method. To produce shale gas, horizontal drilling and hydraulic drilling were performed to create fracture on surrounding wellbore.

Tarakan basin $\left(19,450 \mathrm{~km}^{2}\right)$ was located in northern part of north-east Kalimantan containing deltaic shale layer with good TOC ranging from $1.6-12.1 \%$, mostly type 3 kerogen, thickness of $1000-1500 \mathrm{ft}$ with formation depth of $6.000-16.000 \mathrm{ft}$. Well data indicated Naintupo Formation was in dry gas window with thermal maturity of $1.3-2 \%$. Technically recoverable shale gas reached 5 TCF with 35 TCF risked gas-in-place [2].

Regulation on gross split contract scheme was governed under Regulation of Minister of Energy and Mineral Resources Number 8 of 2017 and Number 52 of 2017. In this contract, gross production would be divided between the state and contractor using base split allocation which is then adjusted by variable component and progressive component.

The purpose of this study was to assess technoeconomic aspect of shale gas field development in Naintupo Formation, Tarakan Basin using gross split contract. The outcome of this paper was to determine reasonable gas price to develop shale gas in this location.

* Corresponding author: wike_tm07@yahoo.com 


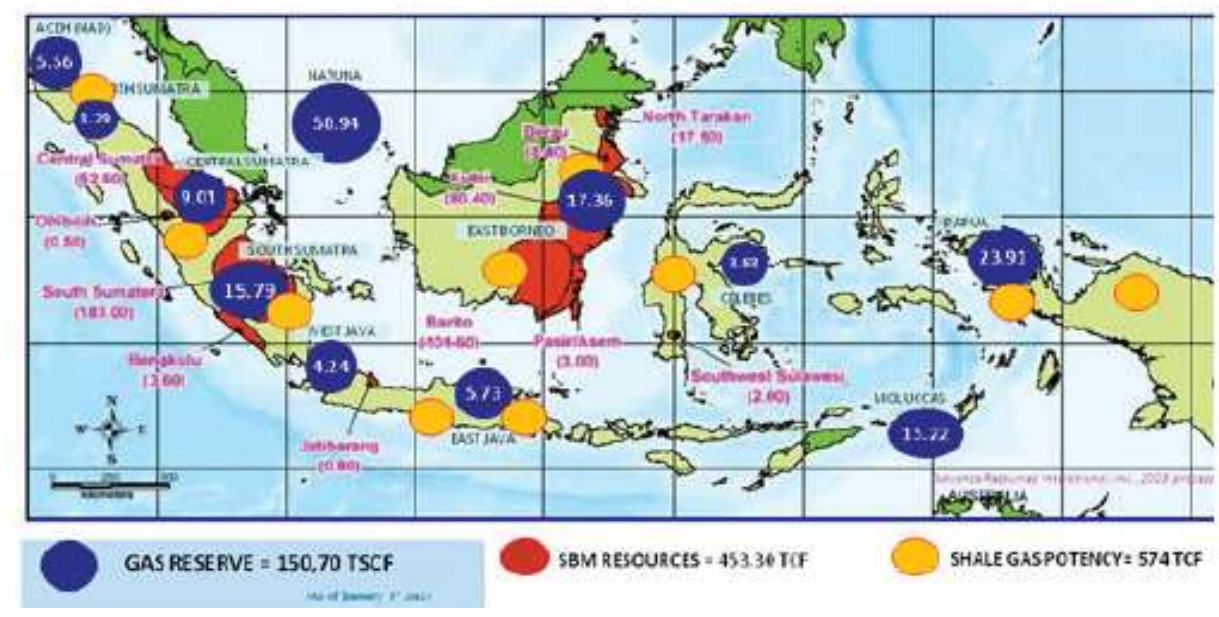

Fig. 1. Indonesia Natural Gas Resource (Kementerian ESDM, 2014)

\section{Method}

The first step of this research procedure was to form problem identification, and then conducted literature study and data collection. Shale gas production profile was developed using hyperbolic decline curve by JJ Arps with its parameters were based on Fayetteville Field production profile in United States. Contract would be conducted in 30 years consist of 10 years of exploration phase and 20 years of exploitation phase. The drilling activity would be conducted during 15 years of exploitation phase with 20 wells were being drilled per annum. Investation costs were based benchmarking cost of developed shale gas field in United States and nearby oil/gas field development in Tarakan Basin. Economic analysis to determine net present value, internal rate of return, profitability index and payback period was conducted on three different flow profile based on gross split contract scheme.

\section{Result and Discussion}

\subsection{Flow profile model}

Flow profile in Naintupo Formation, Tarakan Basin would be modelled based on hyperbolic decline curve [3].

$$
q=q i\left(1+b D_{i} t\right)^{-1 / b}
$$

Where, $q$ is production rate at time $\mathrm{t}, q_{i}$ is initial production rate at start of production, $b$ is the hyperbolic exponent, $D_{i}$ is initial nominal decline rate and $t$ is cumulative time since start of production. Parameters of hyperbolic decline curve equation in Naintupo Formation were based on Fayetteville Field's parameter (Table 1) [4] since the similarity of reservoir fluid which is dry gas in both formation.

Production profile in Naintupo Formation would be divided into three different flow profiles namely low, medium and high flow profile. Fig. 2 showed production profile scenario in Naintupo Formation for all three flow profiles.

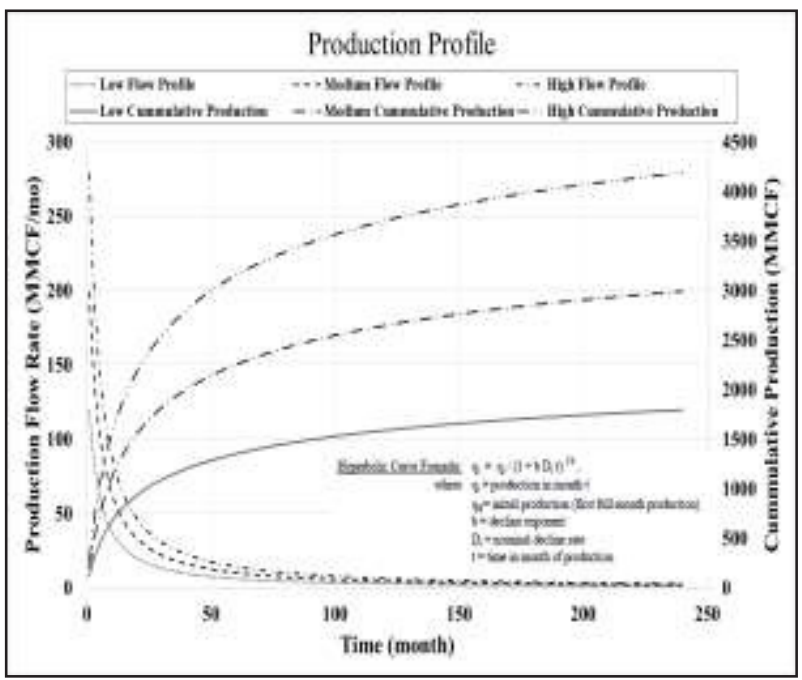

Fig. 2. Flow Profile and Cumulative Production

Parameter $\mathrm{b}$ and $\mathrm{D}_{\mathrm{i}}$ were assumed to be similar in all cases with $b=0.8$ and $\mathrm{Di}=0.25$. During 20 years of exploitation period, shale gas field would produce 494 $\mathrm{BCF}$ in low flow profile, $823 \mathrm{BCF}$ in medium flow profile and 1,152 BCF or $3.3 \%$ of risked gas-in-place in high flow profile (Table 2).

Dry gas produced from this field contained more than $97 \%$ methane and would require dehydration unit to meet pipeline specification. Produced gas would be delivered from wellhead through production header to gas scrubber and entered TEG dehydration package (TEG contractor, TEG regeneration, reboiler and column). Processed gas then would be delivered through assumed $50 \mathrm{~km}$ pipeline to the delivery point.

Table 1. Hyperbolic Decline Curve Parameters in Fayetteville Field [4]

\begin{tabular}{|l|l|l|}
\hline Parameter & \multicolumn{1}{|c|}{ Min } & \multicolumn{1}{c|}{ Max } \\
\hline $\mathrm{q}_{\mathrm{i}(\mathrm{mcf} / \mathrm{mo})}$ & 122,020 & 364,690 \\
\hline $\mathrm{b}$ & 0.7372 & 0.9294 \\
\hline $\mathrm{D}_{\mathrm{i}}$ & 0.1011 & 0.3803 \\
\hline
\end{tabular}


Table 2. Hyperbolic Decline Curve Parameter and Cummulative Production in Naintupo Formation

\begin{tabular}{|l|c|c|c|c|c|}
\hline \multirow{2}{*}{$\begin{array}{c}\text { Flow } \\
\text { Profile }\end{array}$} & \multicolumn{2}{|c|}{ Arps Parameter } & \multicolumn{2}{c|}{$\begin{array}{c}\text { Cummulative } \\
\text { Production (mmcf) }\end{array}$} \\
\cline { 2 - 6 } & $\begin{array}{c}\mathbf{q i} \\
\text { (mmcf/ } \\
\text { mo) }\end{array}$ & $\mathbf{b}$ & $\mathbf{D}_{\mathbf{i}}$ & Well & Field \\
\hline Low & 150 & 0.8 & 0.25 & $1,794.8$ & 494,012 \\
\hline Medium & 250 & 0.8 & 0.25 & $2,991.3$ & 823,353 \\
\hline High & 350 & 0.8 & 0.25 & $4,187,9$ & $1,152,694$ \\
\hline
\end{tabular}

\subsection{Field development investation cost}

Investation costs for shale gas development would be divided into two main component, capital expenditure (capex) and operating expenditure (opex). Costs during exploration period includes geology, geophysics and seismic cost, drilling and stimulation cost for twenty exploration wells. These 20 exploration wells were assumed would be produced on the eleventh year of the contract period or in the first year of exploitation period. Costs estimation on three flow profiles were shown in Table 3.

Table 3. Cost Parameter for Base Case

\begin{tabular}{|l|c|c|c|}
\hline \multirow{2}{*}{ Cost Parameter } & \multicolumn{3}{|c|}{ Flow Profile } \\
\cline { 2 - 4 } & Low & Medium & High \\
\hline $\begin{array}{l}\text { Geology, Geophysics and } \\
\text { Seismic (MM \$) }\end{array}$ & 40.54 & 40.54 & 40.54 \\
\hline $\begin{array}{l}\text { Drilling Cost per well } \\
\text { (MM \$) }\end{array}$ & 5.22 & 5.22 & 5.22 \\
\hline $\begin{array}{l}\text { Hydraulic Fracturing } \\
\text { Cost per well (MM \$) }\end{array}$ & 4.13 & 4.13 & 4.13 \\
\hline $\begin{array}{l}\text { Peak Production } \\
\text { (MMCFD) }\end{array}$ & 140.00 & 233.33 & 326.67 \\
\hline $\begin{array}{l}\text { Processing Facility Cost } \\
\text { (MM \$) }\end{array}$ & 47.99 & 65.20 & 79.78 \\
\hline $\begin{array}{l}\text { TEG dehydration unit } \\
\text { cost (MM \$) }\end{array}$ & 10.65 & 14.47 & 17.71 \\
\hline Pipeline Diameter (inch) & 16.00 & 20.00 & 22.00 \\
\hline Pipeline Cost(MM \$) & 49.93 & 56.20 & 59.34 \\
\hline
\end{tabular}

Capital expenditure consists of tangible and intangible cost. Tangible cost was dedicated for appliances which had salvage value such as casing, tubing and wellhead. Intangible cost had no salvage value such as labour, chemical and drilling fluid cost and counted in the year of service. For this study, drilling cost was assumed to have $20 \%$ tangible cost and pipeline's tangible cost was $30 \%$. For gross split contract, production facility's tangible cost would be depreciated $25 \%$ in five years. Operation cost was assumed \$1/MMBTU. Both capex and opex would have $3 \%$ price escalation.

\subsection{Gross split contract scheme}

Gross split contract scheme was governed under Regulation of Minister of Energy and Mineral Resources
Number 8 of 2017 [5] and Number 52 of 2017 [6]. These regulations set a new economic structure in oil and gas industry in Indonesia in which the revenue for contractor and government would be based on split gross production without cost recovery mechanism. The gross split contract consists of three main components which are base split allocation, variable component and progressive component. The base split allocation on gross production would then be adjusted using variable component and progressive component in order to determine final split between government and contractor. For gas field, the base split would be $52 \%$ for government and $48 \%$ for contractor. The base split would be adjusted with variable components such as the working area status, the field location, the reservoir depth, the availability of supporting infrastructure, the reservoir type, the carbon dioxide content, the hydrogen sulphide content, the crude oil specific gravity, the level of domestic components in the field development period and the production phase. The progressive components referred to gas price and oil/gas cumulative production.

Table 4. Base Split and Variable Components for Shale Gas Field

\begin{tabular}{|l|c|c|}
\hline \multicolumn{1}{|c|}{ Component } & Parameter & $\begin{array}{c}\text { Contractor } \\
\text { Split (\%) }\end{array}$ \\
\hline Base Split & - & 48.0 \\
\hline Variable Components & POD 1 & 5.0 \\
\hline - Working Area & Onshore & 0.0 \\
\hline - Field location & $>2500 \mathrm{~m}$ & 1.0 \\
\hline - Reservoir depth & Well Developed & 0.0 \\
\hline $\begin{array}{l}\text { - Availability of } \\
\text { supporting infrastructure }\end{array}$ & Unconventional & 16.0 \\
\hline - Reservoir type & $<5 \%$ & 0.0 \\
\hline - Carbon dioxide content & $<100$ ppm & 0.0 \\
\hline $\begin{array}{l}\text { - Hydrogen sulphide } \\
\text { content }\end{array}$ & $30 \leq \mathrm{x} \leq 50$ & 2.0 \\
\hline $\begin{array}{l}\text { - Level of domestic } \\
\text { component }\end{array}$ & Primary & 0.0 \\
\hline - Production phase & &
\end{tabular}

Table 5. Progressive Components for Gross Split Contract

\begin{tabular}{|l|l|c|}
\hline $\begin{array}{c}\text { Progressive } \\
\text { Component }\end{array}$ & \multicolumn{1}{|c|}{ Parameter } & $\begin{array}{c}\text { Contractor Split } \\
(\mathbf{\%})\end{array}$ \\
\hline \multirow{3}{*}{$\begin{array}{l}\text { Gas price } \\
\text { (US } \$ \text { /MMBTU) }\end{array}$} & $<7$ & $(7-$ gas price $) \times 2.5$ \\
\cline { 2 - 3 } & $7-10$ & 0.0 \\
\cline { 2 - 3 } & $>10$ & $(10-$ gas price $) \times 2.5$ \\
\hline \multirow{4}{*}{$\begin{array}{l}\text { Cummulative oil } \\
\text { and gas production } \\
\text { (MMBOE) }\end{array}$} & $<30$ & 10.0 \\
\cline { 2 - 3 } & $30 \leq \mathrm{x}<60$ & 9.0 \\
\cline { 2 - 3 } & $90 \leq \mathrm{x}<90$ & 8.0 \\
\cline { 2 - 3 } & $125 \leq \mathrm{x}<175$ & 6.0 \\
\cline { 2 - 3 } & $\geq 175$ & 4.0 \\
\hline
\end{tabular}

In developing shale gas field in Naintupo Formation, Tarakan Basin, contractor would take $72 \%$ of gross 
revenue consisted of $48 \%$ base split and $24 \%$ additional split on variable components as were shown in Table 4. Those contractor split would be adjusted with progressive components as were shown in Table 5.

Tax treatment on gross split contract was regulated under Government Regulation Number 53 of 2017 [7]. There are seven fiscal incentives offered by government to contractor from exploration and exploitation stage until the commencement of the oil/gas production, which are import duty free on oil/gas operation goods, VAT and sales tax on luxury goods are not levied on the acquisition and utilization on the oil/gas products and services, income tax article 22 is not levied on oil/gas operation goods imports, $100 \%$ reduction on land and building tax, oil/gas joint asset utilization (cost sharing) is not subject to VAT, loss carry forward operation cost as reduction of taxable income is extended from 5 years to 10 years and indirect cost of head office is not subject to VAT. For gross split analysis in this study, tax of $44 \%$ would be used.

\subsection{Economic analysis on base case}

Economic analysis was conducted on three different flow profile with $10 \$$ of gas price on delivery point. Escalation factor of gas price would be $1.3 \%$ as per growth of natural gas price in 2007-2050 in Pacific area [8]. Costs escalation factor was assumed $3 \%$ each year. Economic analysis would calculate economic indicators such as NPV (net present value), IRR (internal rate of return), PI (profitability index) and payback period. On the Pedoman Tata Kerja SKK Migas No. PTK037/SKKMA000/2017/S0 on Plan of Development (POD) [9], discount factor of $10 \%$ was suggested to calculate present value. A project was considered gave added value to a company if NPV $>0$, IRR $>10 \%$, PI $>1$ and have shorter payback period.

In this analysis, medium and high flow profile gave positive results on NPV, IRR and PI (Table 6) with NPV in medium flow profile reached 242.32 MM\$ with IRR of $16.71 \%$ and NPV in high flow profile was 782.96 MM\$ with 31.05\% IRR. Low flow profile gave negative NPV and IRR was below $10 \%$ which made shale gas development was considered uneconomical at this flow profile.

On the gross split contract, contractor's revenue was pure from base split, variable component and progressive component allocation. The contractor take and the government take from each flow profile were shown in Table 7. At the end of the contract period, the contractor's take was 6,036.4 MM\$ in medium flow profile and \$7,690.2 MM\$ in high flow profile. Contractor's revenue would be subtracted with $44 \%$ tax. If revenue couldn't cover operation cost, the loss will be compensated with revenue starting with next tax year up until 10 years or commonly known as "loss carry forward". In medium and high flow profile, "loss carry forward" gave advantage to contractor since contractor was tax free when the revenue didn't cover its expenses. Contractor started to pay tax on the $5^{\text {th }}$ year of exploitation stage in medium flow profile and on the $3^{\text {rd }}$ year in high flow profile.

Table 6. Economic Indicators in Gross Split Contract

\begin{tabular}{|c|c|c|c|c|}
\hline $\begin{array}{c}\text { Flow } \\
\text { Profile }\end{array}$ & $\begin{array}{c}\text { NPV } \\
\text { (MM \$) }\end{array}$ & $\begin{array}{c}\text { IRR } \\
\text { (\%) }\end{array}$ & PI & $\begin{array}{c}\text { Payback } \\
\text { Period } \\
\text { (years) }\end{array}$ \\
\hline Low & -465.65 & -2.48 & -0.39 & N/A \\
\hline Medium & 242.32 & 16.71 & 1.67 & 6.23 \\
\hline High & 782.96 & 31.05 & 3.04 & 3.47 \\
\hline
\end{tabular}

Table 7. Contractor Take and Government Take in Gross Split Contract

\begin{tabular}{|c|c|c|c|c|c|}
\hline \multirow{2}{*}{$\begin{array}{c}\text { Flow } \\
\text { Profile }\end{array}$} & \multicolumn{2}{|c|}{$\begin{array}{c}\text { Contractor } \\
\text { Take }\end{array}$} & \multicolumn{2}{c|}{$\begin{array}{c}\text { Government } \\
\text { Take }\end{array}$} & Total \\
\cline { 2 - 6 } & (MM\$) & $\mathbf{( \% )}$ & (MM\$) & $\mathbf{( \% )}$ & (MM\$) \\
\hline Low & $4,074.2$ & 73.3 & $1,481.8$ & 26.7 & $5,555.9$ \\
\hline Medium & $6,042.9$ & 65.3 & $3,217.0$ & 34.7 & $9,259.9$ \\
\hline High & $7,696.7$ & 59.4 & $5,267.1$ & 40.6 & $12,963.9$ \\
\hline
\end{tabular}

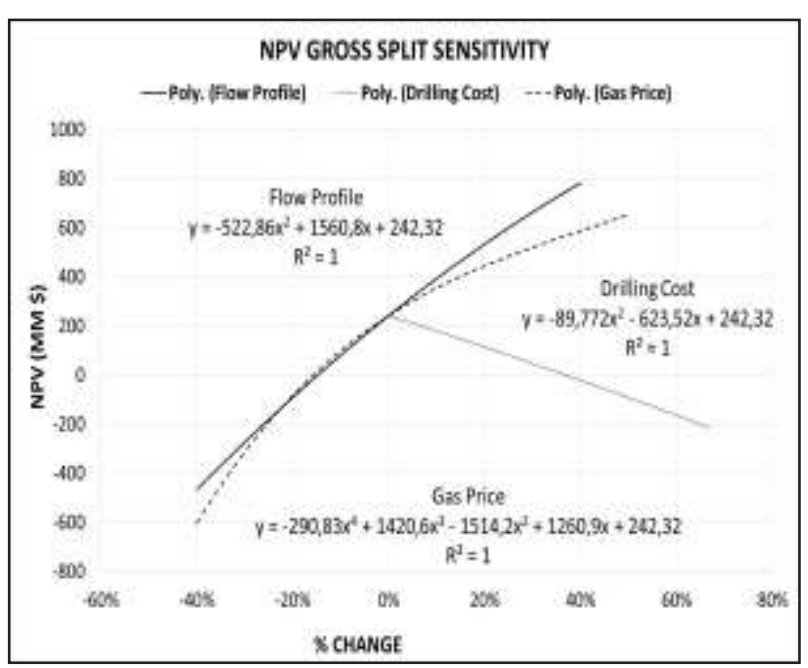

Fig. 3. NPV Sensitivity Char

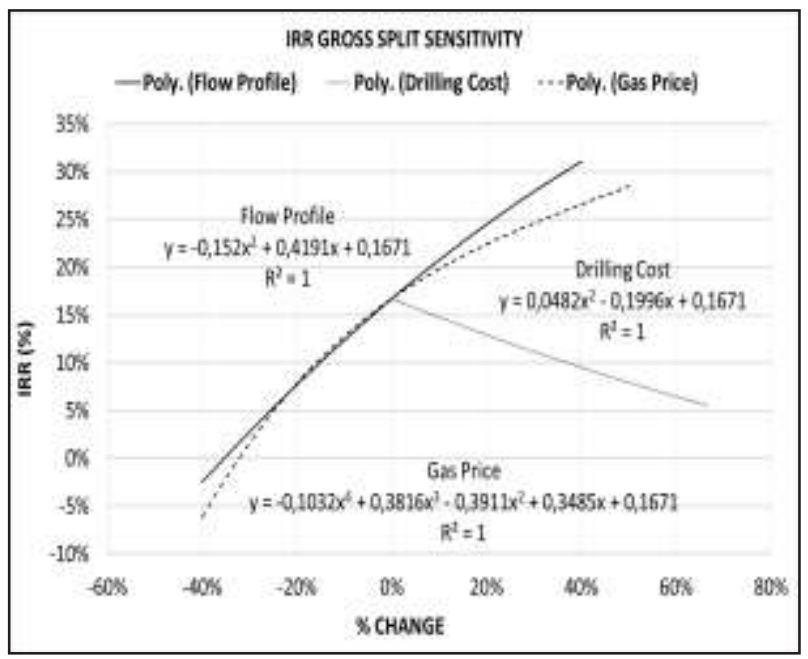

Fig. 4. IRR Sensitivity Chart 


\subsection{Sensitivity analysis}

In the sensitivity analysis, medium flow profile would act as base case with $\$ 10$ gas price on the delivery point. Sensitivity analysis was conducted on drilling cost as part of capital expenditure, flow profile and gas price. In the gross split contract, increased flow profile and gas price gave positive impact to NPV (Fig. 3) and IRR (Fig. 4) with similar effects were observed on PI and payback period. On the other hand, increased drilling cost gave the opposite result.

The gas price and flow profile gave almost similar NPV and IRR when change percentage was on $-25 \%$ and $5 \%$ range. When change percentage was more than 5\%, the change of flow profile gave more effect on NPV and IRR increased than the gas price. The gas price was more influential when percentage change was below $-25 \%$.

\subsection{Price recommendation}

NPV was one of economic indicators which determine whether a project could be executed. A project was considered to be run when NPV gave positive value on its calculation.

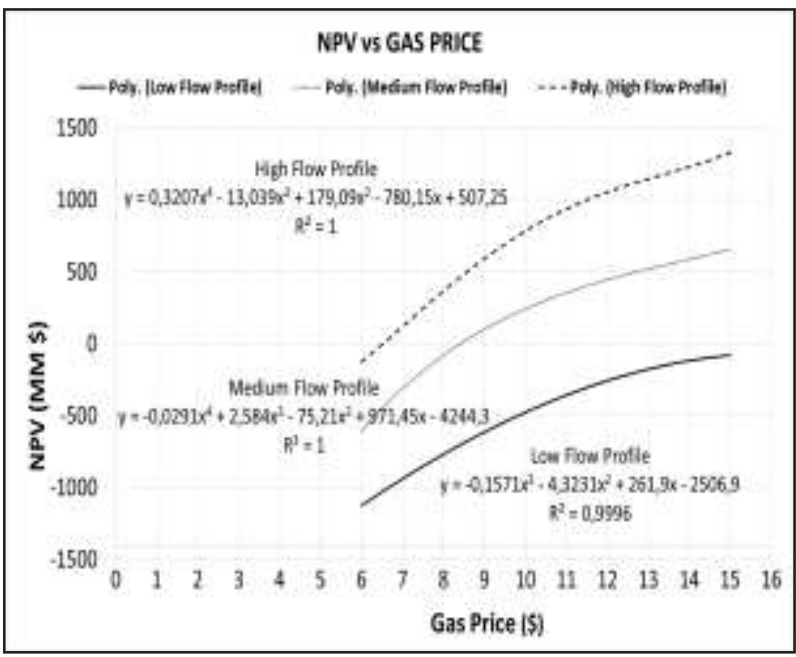

Fig. 5. NPV vs Gas Price

Fig. 5 showed NPV on each flow rate when it was sold on different gas price. Discount rate of $10 \%$ was applied on calculation. To give NPV $>0$, shale gas should be produced in high flow profile with the gas price above $\$ 6.52 / \mathrm{MMBTU}$ or in medium flow profile with the gas price above $\$ 8.42 / \mathrm{MMBTU}$.

\section{Conclusion}

The development of shale gas field should be considered as one option to minimize gas deficit in upcoming years. In high flow profile, produced shale gas reached 1,152 $\mathrm{BCF}$ or $3.3 \%$ of risked gas-in-place during 20 years of exploitation period. To develop positive NPV, shale gas should be produced in medium flow profile with minimum price of $\$ 8.42 / \mathrm{MMBTU}$ or in high flow profile with minimum price of $\$ 6.52 / \mathrm{MMBTU}$.
This research was partially funded by "Hibah Publikasi Internasional Terindeks Tugas Akhir Mahasiswa Universitas Indonesia 2018 Contract No. 2500/UN2.R3.1/HKP.05.00/2018” from Directorate Research and Community Service Universitas Indonesia. The authors declare no competing interests or any conflicts of financial interests.

\section{References}

1. Kementerian ESDM, Peta Jalan Kebijakan Gas Bumi Nasional 2014 - 2030, Jakarta: Kementerian ESDM, (2014).

2. M. A. Berawi, P. Miraj, A. R. B. Berawi, Silvia and F. Darmawan, "Towards Self-Sufficient Demand in 2030 : Analysis of Life-Cycle Cost for Indonesian Energy Infrastructure," International Journal of Technology, vol. 7, no. 8, pp. 1445-1454, 2016.

3. EIA, "Technically Recoverable Shale Oil and Shale Gas Resources : Indonesia," U.S. Energy Information Administration, Washington, DC, (2015).

4. J. J. Arps, "Analysis of Decline Curves," Houston Meeting, pp. 228-247, (1944).

5. e. a. Fanchi, "Probabilistic Decline Curve Analysis of Barnett, Fayetteville, Haynesville and Woodford Gas Shales," Journal of Petroleum Science and Engineering, pp. 308-311, (2013).

6. Menteri Energi dan Sumber Daya Mineral Republik Indonesia, "Permen ESDM No. 8 Tahun 2017," Kementerian Energi dan Sumber Daya Mineral, Jakarta, (2017).

7. Menteri Energi dan Sumber Daya Mineral Republik Indonesia, "Permen ESDM No. 52 Tahun 2017," Kementerian ESDM, Jakarta, (2017).

8. PP No. 53, "Peraturan Pemerintah Republik Indonesia Nomor 53 Tahun 2017," Jakarta, (2017).

9. EIA, "Annual Energy Outlook 2018," (2018). [Online].

10. SKK Migas, "Pedoman Tata Kerja Nomor: PTK037/SKKMA0000/2017/S0 (Revisi 1)," SKK Migas, Jakarta, (2017). 